\title{
Diadema ascensionis Mortensen, 1909 (Echinodermata: Echinoidea) is not restricted to Oceanic Islands: evidence from morphological data
}

\author{
Gondim, AI. ${ }^{a *}$, Dias, TLP. $^{b}$ and Christoffersen, ML. ${ }^{a}$ \\ a'Laboratório de Invertebrados Paulo Young, Programa de Pós-graduação em Ciências Biológicas (Zoologia), \\ Departamento de Sistemática e Ecologia, Centro de Ciências Exatas e da Natureza - CCEN, \\ Universidade Federal da Paraíba - UFPB, Cidade Universitária, CEP 58051-900, João Pessoa, PB, Brazil \\ ${ }^{b}$ Departamento de Biologia, Laboratório de Biologia Marinha, Universidade Estadual da Paraíba - UEPB, \\ Campus I, Rua das Baraúnas, 351, Bairro Universitário, CEP 58429-500, Campina Grande, PB, Brazil \\ *e-mail: anneisabelley@yahoo.com.br
}

Received May 17, 2012 - Accepted July 20, 2012 - Distributed May 31, 2013

(With 2 figures)

\begin{abstract}
The genus Diadema presently consists of seven species, two of which are known from the Brazilian coast: D. antillarum and $D$. ascensionis. The first is usually known for shallow coastal areas, while the second was apparently restricted to oceanic islands. In February 2011, a dense population of D. ascensionis was observed on the coastal reefs of Praia do Francês (Alagoas State, northeastern Brazil). Five specimens were collected and transported to the laboratory where morphological studies of the test and pedicellariae were conducted. Subsequently, visits were made to scientific collections in order to compare and confirm species identifications. Our observations confirm the presence of tridentate pedicellariae with narrow and strongly curved valves. The axial cavity in the tips of the spines is filled with dense nonreticular tissue. This taxonomic data confirms the occurrence of $D$. ascensionis in coastal areas. On the coastal reefs of Praia do Francês, animals were observed from the beach to the reef formations about $200 \mathrm{~m}$ offshore in areas with a sandy substrate and in reef cavities, usually in clear and well illuminated waters. Solitary individuals or groups of up to 15 individuals formed dense populations in the area. We stress the importance of pedicellariae for the specific identification of the Diadematidae, considering that they are quite constant and reliable at this taxonomic level. Our results demonstrate that $D$. ascensionis is not restricted to insular environments and that this species may be common in shallow coastal habitats.
\end{abstract}

Keywords: Diadematidae, pedicellariae, sea urchins, Brazil, taxonomy.

\section{Diadema ascensionis Mortensen, 1909 (Echinodermata: Echinoidea) não está restrito a Ilhas Oceânicas: evidências de dados morfológicos}

\begin{abstract}
Resumo
O gênero Diadema é composto por sete espécies, das quais duas são conhecidas para o litoral brasileiro: D. antillarum e D. ascensionis. A primeira é principalmente conhecida em áreas costeiras, enquanto que a segunda está aparentemente restrita a ilhas oceânicas. Em fevereiro de 2011, uma densa população de $D$. ascensionis foi observada nos recifes costeiros da Praia do Francês, no Estado de Alagoas, Região Nordeste do Brasil. Cinco espécimes foram coletados e transportados ao laboratório, onde estudos morfológicos da carapaça e das pedicelárias foram desenvolvidos. Subsequentemente, foram realizadas visitas a coleções científicas para a comparação e a confirmação da espécie. As observações, neste trabalho, evidenciaram a presença de uma pedicelária tridentada com valvas estreitas e fortemente curvadas. A cavidade axial nas pontas dos espinhos é preenchida por um denso tecido não reticular. Estes dados taxonômicos confirmam a ocorrência de D. ascensionis em áreas costeiras. Nos recifes costeiros da Praia do Francês, os animais foram observados a partir da praia em direção às formações recifais localizadas a $200 \mathrm{~m}$ da praia, em áreas de substrato arenoso, e nas cavidades do recife, geralmente em águas claras e bem iluminadas. Os indivíduos estavam solitários ou formando grupos de até 15 indivíduos. Destaca-se a importância das pedicelárias na sistemática dos Diadematidae, tendo em vista que as mesmas são bastante constantes e confiáveis para a identificação em nível específico. Os resultados do presente trabalho demonstram que D. ascensionis não está restrita a ambientes insulares e que esta espécie pode ser comum em habitats costeiros rasos.
\end{abstract}

Palavras-chave: Diadematidae, pedicelárias, ouriços-do-mar, Brasil, taxonomia. 


\section{Introduction}

Diadema Gray, 1825 is one of the most abundant, widespread, and ecologically important shallow water genera of tropical seas (Lessios et al., 2001). Presently the genus has seven species (Kroh and Mooi, 2011), two of which are known from the Brazilian coast: $D$. antillarum Philippi, 1845 and D. ascensionis Mortensen, 1909. The first is usually known for shallow coastal areas (from 0 to $400 \mathrm{~m}$, being most common in depths below $50 \mathrm{~m}$ ), while the second was apparently restricted to oceanic islands (Pawson, 1978).

Since its original description, the taxonomic status of Diadema ascensionis has been the subject of considerable discussion, having once been considered a synonym or a subspecies of $D$. antillarum. Presently it is considered a valid species, although molecular and morphological data conflict over the status of the two taxa (Lessios et al., 2001; Coppard and Campbell, 2004, 2006a, b).

In this study, we record dense populations of D. ascensionis in coastal waters. We provide a morphological description that allows its distinction from $D$. antillarum. We also provide information on the habitat of $D$. ascensionis and discuss the importance of the pedicellariae for the correct identification of the species.

\section{Material and Methods}

In February 2011, five specimens of Diadema were collected by hand from the coastal reefs of the Praia do Francês ( $9^{\circ} 46^{\prime} 07^{\prime}$ ' S and $35^{\circ} 50^{\prime}$ '05' W) (see Figure 1a), in the state of Alagoas (northeast Brazil), while diving about $2 \mathrm{~m}$ below the surface during lowest tides $(1 \mathrm{~m})$. These reefs form an extensive fringe parallel to the coast, with approximately $3.5 \mathrm{~km}$ in the north/south direction and are located about $240 \mathrm{~m}$ from the beach (see Figure 1a). After collection, the animals were transported to the laboratory and fixed in formalin $10 \%$, being deposited in the Echinoderm section of the Paulo Young Invertebrate Collection, at the Federal University of Paraíba (CIPY-UFPB).

For the correct identification of specimens, the morphologies of the naked test, of the pedicellariae, and of the spines were observed (Mortensen, 1909; Tommasi, 1966; Coppard and Campbell, 2004; 2006a, b). In order to produce photos of the valves of selected tridentate pedicellariae with a scanning electron microscopy (SEM), these were placed in solutions of sodium hipochloride $(\mathrm{NaClO})$ (household bleach) at $2.5 \%$ and neutralised with sodium bicarbonate $\left(\mathrm{NaHCO}_{3}\right)(1 \mathrm{~mL}$ of $\mathrm{NaClO}+10 \mathrm{~mL}$ of $\mathrm{NaHCO}_{3}$ in a concentration of $0.5 \mathrm{Mol} / \mathrm{L}$ ) to remove the soft tissue and expose the underlying calcareous ossicles. The valves of the pedicellariae were then washed in distilled water and dried in absolute ethanol. They were subsequently mounted on aluminum stubs and sputter coated in gold.

Preserved specimens of Diadema from the Echinoderm Collection of CIPY-UFPB, Laboratório de Invertebrados Marinhos da Universidade Federal de Sergipe (LABIMARUFS), Museu de Zoologia da Universidade Federal da Bahia (MZUFBA), Museu de Zoologia da Universidade de São Paulo (MZUSP) and the Museu Nacional do Rio de Janeiro (MNRJ) were analysed and compared with the collected specimens.

\section{Results}

Twelve specimens of Diadema ascensionis were analysed, coming from Ilha da Rata, Fernando de Noronha Archipelago (Pernambuco state) $(\mathrm{n}=1$ specimen), Praia do Francês Reefs (Alagoas state) $(\mathrm{n}=10$ specimens), and Itapuã Beach (Bahia state) $(n=1$ specimen). A total of 150 pedicellariae, 100 of which tridentate, 25 claviform and 25 triphyllous, were extracted from this material.

Specimens are black in colour, with blue lines in the interambulacral zones and around the apical system (usually completely black) (see Figure 1). The periproct has a small black anal cone. The spines are long, thin, hollow, the axial cavities in tips of spines being filled with dense non-reticular tissue. Pedicellariae tridentate, with narrow and strongly curved valves (see Figure $2 \mathrm{f}$, g). Claviform pedicellariae are distributed around spines. Triphyllous pedicellariae are distributed all over the body surface. The naked test is white, circular, with oral region flat (see Figure $2 \mathrm{a}, \mathrm{b}$ ). Peristomial region twice as large as region of periproct. The apical system is depressed, ocular plates I, IV and VI inserted on hemicyclic (see Figure 2c). The ocular plates have one or two small tubercles (see Figure 2c). Ambulacral plate trigeminate. The ambulacral zone is inflated and narrow $( \pm 9.12 \mathrm{~mm})$. The interambulacral zone is large $( \pm 38.64 \mathrm{~mm})$.

On the coastal reefs of Praia do Francês, animals were observed from the beach to the reef formations about $200 \mathrm{~m}$ offshore (see Figure 1b-d), in depths of 1-4 m. They were found in areas with a sandy substrate and in reef cavities, usually in clear and well illuminated waters. Individuals were solitary of formed groups (see Figure 1d) of up to 15 individuals, forming dense populations in the area. In some areas of the reef we observed $D$. ascensionis with Echinometra lucunter, the latter also abundant in the studied area. However, a visual analysis indicated that E. lucunter is concentrated in the shallower portions of the reef, usually in deep burrows built into the rock. On the other hand, D. ascensionis seems to prefer subtidal waters, in sandy substrates close to rocks, and not always being positioned within cavities in the rocks.

In the areas where D. ascensionis was found, we usually observed other echinoderms, such as the crinoid Tropiometra carinata carinata and the two-mentioned species of sea-urchins. In some sectors of the reef, rocks to which $D$. ascensionis was associated were densely covered by the zoanthid Palythoa caribbaeorum and filamentous algae (see Figure 1b). Young specimens of D. ascensionis were also observed among colonies of the fire-coral, Millepora alcicornis (see Figure 1c).

\section{Discussion}

Species of family Diadematidae are taxonomically complex, being difficult to distinguish from each other. 

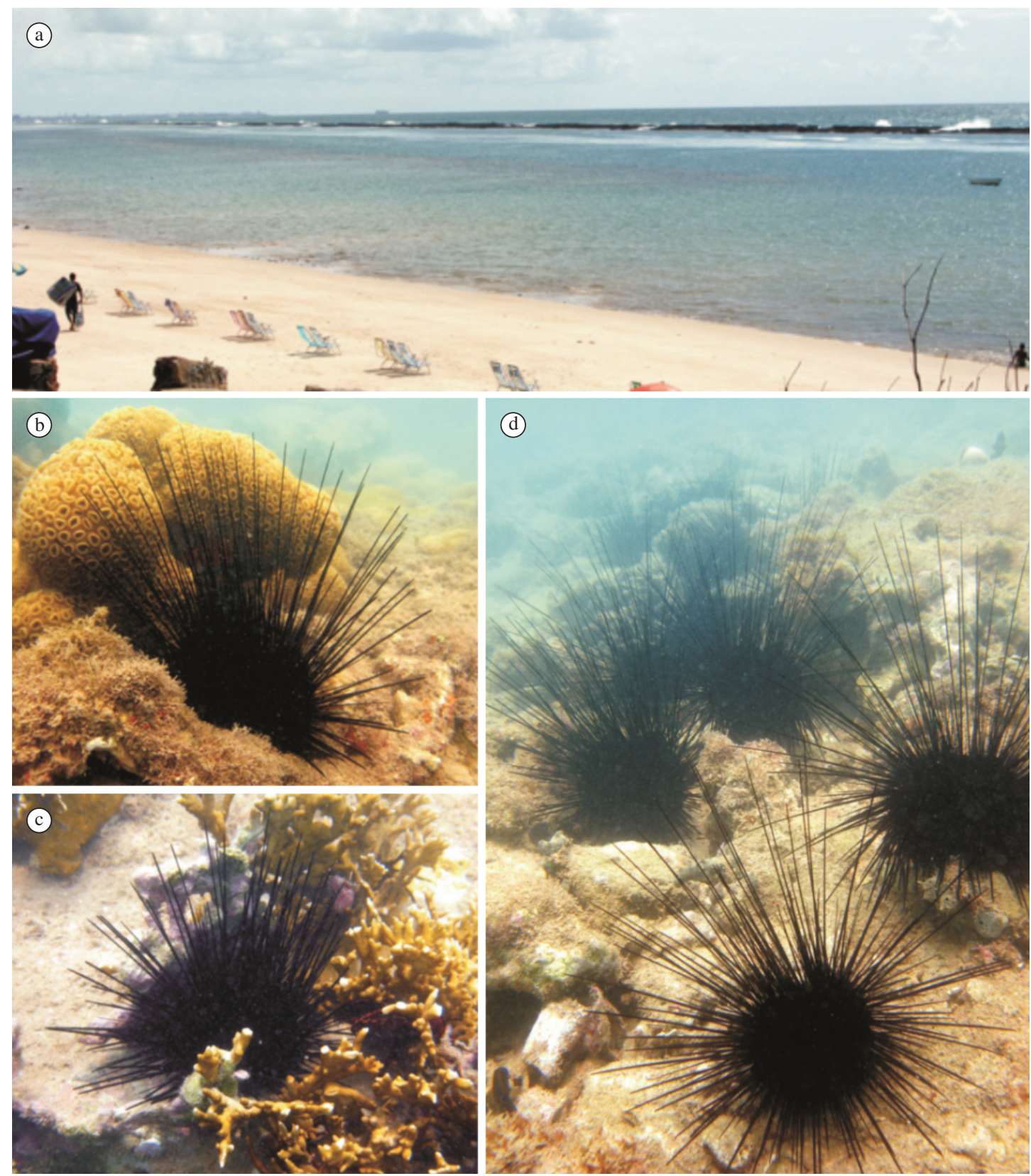

Figure 1. (a) Partial view of Praia do Francês reefs, Alagoas State, northeast Brazil, (b) Diadema ascensionis near rocks covered by the zoanthid Palythoa caribaeorum, (c) Juvenile Diadema ascensionis among the branches of the fire coral Millepora alcicornis, (d) Small group of adult individuals over rocky bottom. Photographs by T. L. P. Dias.

Morphological differences between species are sometimes so slight that specimens usually cannot be identified without previous knowledge on the collecting site (Coppard and Campbell, 2006a). Accurate observations of the spines and pedicellariae are also necessary for identification. Morphological comparisons of the test, spines and pedicellariae between specimens from continental and insular habitats revealed that the Brazilian specimens from coastal habitats of Praia do Francês, previously identified as Diadema antillarum, are in reality D. ascensionis.
Consequently, the latter species is not restricted to oceanic islands, as previously thought.

Diadema antillarum and D. ascensionis are closely related species, being very similar both morphologically and genetically. Previously they were considered synonyms (Pawson, 1978; Lessios et al., 2001). Recent studies of Coppard and Campbell (2004, 2006a, b), who evaluated the systematic significance of spines, pedicellariae, and test in species of genus Diadema, established the validity of the two species. Diadema ascensionis differs from 

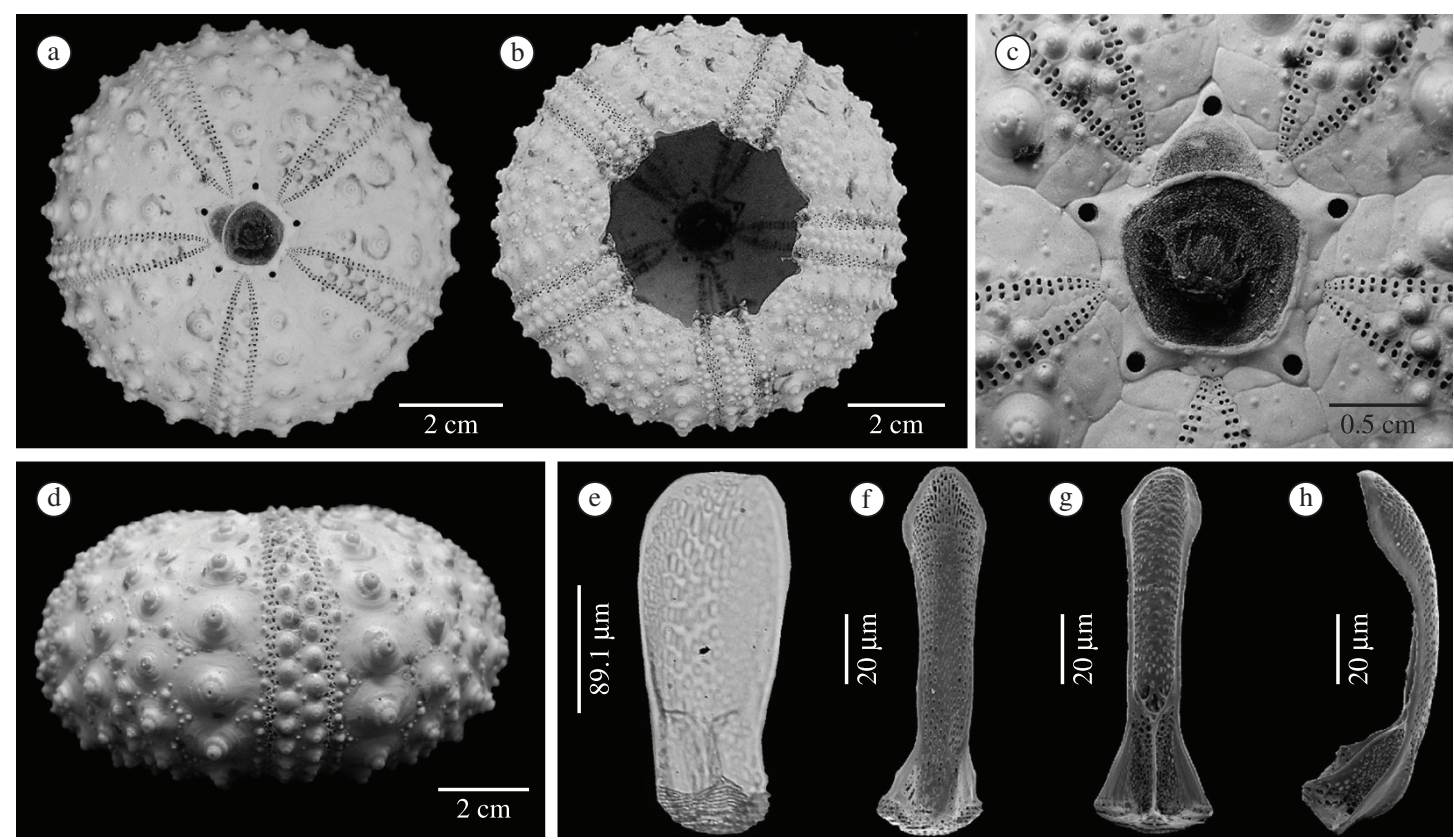

Figure 2. Diadema ascensionis (a) Dorsal view of test, (b) Oral view of test, (c) Detail of apical system, (d) Lateral view of test; (e) Valve ossicle of a triphyllous pedicellariae (optic microscope), (f) Dorsal view of valve ossicle of tridentate pedicellariae, (g) Internal view of valve ossicle of tridentate pedicellariae, (h) Lateral view of valve ossicle of tridentate pedicellariae (SEM).

D. antillarum for possessing strongly curved valves in the tridentate pedicellariae, genital plates being with or without a single tubercle, and axial cavities in the tips of the spines being filled with dense non-reticular tissue.

Pedicellariae represent an important character in the identification of echinoids, but they are unfortunately neglected in some recent taxonomic studies. Mortensen (1940) considered pedicellariae to furnish the most stable and least variable characters within individual urchin species, and hence they are valuable when identifying similar or commonly confused species (Coppard and Campbell, 2006a). Within the genus Diadema, the morphology of the tridentate pedicellariae represents a key character for species identification. Coppard and Campbell (2006b) analysed and illustrated the tridentate pedicellariae for all species of Diadema and concluded that the tridentate pedicellariae of $D$. ascensionis are consistently different from all other species of the genus.

Differently from its congener Diadema antillarum, which represents one of the most widely studied species from an ecological point of view, biological and ecological information is unavailable for $D$. ascensionis. Personal observations suggest that both species use the same habitats, and may co-occur in the same reefs. Apparently D. ascensionis has a mode of life very similar to that of $D$. antillarum. Like D. antillarum, D. ascensionis may form dense populations in coastal habitats and may play a fundamental role in controlling populations of macroalgae. In the reefs of Praia do Francês, the young specimens of
D. ascensionis have a similar habit as that described by Millott (1953) for the young of $D$. antillarum observed in reefs of Jamaica, where the young found along the margins of the reefs were established within burrows. Because both species are easily confused, much ecological information provided for $D$. antillarum may actually be attributable to D. ascensionis.

In conclusion, considering that the pedicellariae provide very stable identification criteria, their importance for the correct identification of the Diadematidae is emphasized. Our results demonstrate that $D$. ascensionis is not restricted to insular environments, occurring also in shallow coastal habitats. In order to separate both species correctly, it is necessary to conduct a detailed analysis of the pedicellariae and of the structure of the spines. Ecological research on life habits and environmental interactions in reef habitats may provide further distinguishing characters between the two species.

Acknowledgements - We would like to thank L.C.P. Damasceno for his fundamental help in field work. Dr. C.R.R. Ventura (Museu Nacional do Rio de Janeiro) kindly facilitated access to the scanning electron microscope. We are also grateful to A. Benetti (MZUSP), C.M. Menengola (MZUFBA) and C. L. C. Manso (UFS) for permitting us to examine material deposited under their charge. A.I. Gondim was supported by CAPES (the Brazilian Ministry of Education) through a Master's scholarship and M.L. Christoffersen was supported with a productivity grant from Conselho Nacional de Desenvolvimento Científico e Tecnológico (CNPq). 


\section{References}

COPPARD, SE. and CAMPBELL, AC., 2004. Taxonomic significance of spine morphology in the echinoid genera Diadema and Echinothrix. Invertebrate Biology, vol. 123, no. 4, p. 357-371.

-, 2006a. Taxonomic significance of test morphology in the echinoid genera Diadema Gray, 1825 and Echinothrix Peters, 1853 (Echinodermata). Zoosystema, vol. 28, no. 1, p. 93-112.

-, 2006b. Systematic significance of tridentate pedicellariae in the echinoid genera Diadema and Echinothrix. Invertebrate Biology, vol. 125, no. 4, p. 363-378. http://dx.doi.org/10.1111/j.17447410.2006.00068.x

LESSIOS, HA., KESSING, BD., and PEARSE, JS., 2001. Populations structure and speciation in tropical seas: global phylogeny of the sea urchin Diadema. Evolution, vol. 55, no. 5, p. 955-975. http:// dx.doi.org/10.1554/0014-3820(2001)055[0955:PSASIT]2.0.CO;2
KROH, A. and MOOI, R., 2011. World Echinoid Database. Available from: <http://www.marinespecies.org/echinoidea>. Access in: 02 July 2012.

MILLOTT, N., 1953. Some preliminary observations on the young forms of the Echinoid, Diadema antillarum Philippi. Bulletin of Marine Science, vol. 2, no. 3, p. 498-510.

MORTENSEN, T., 1909. Die Echinoiden der Deutschen SüdpolarExpedition 1901-1903. p. 1-114.

-, 1940. Monograph of the Echinoidea. Copenhagen: Aulodonta. C. A. Reitzel. vol. I11, p. 1-533.

PAWSON, DL., 1978. The echinoderm fauna of Ascension Island, South Atlantic Ocean. Smithsonian Contribution to the Marine Science, no. 2, p. 1-31.

TOMMASI, LR., 1966. Lista dos equinóides recentes do Brasil. Contribuições do Instituto Oceanográfico, Série Oceanografia Biológica, no. 11, p. 1-50. 